\title{
BUDIDAYA IKAN HIAS SEBAGAI PENDUKUNG PEMBANGUNAN NASIONAL PERIKANAN DI INDONESIA
}

\author{
Eni Kusrini \\ Balai Riset Budidaya Ikan Hias \\ Jl. Perikanan No. 13 Pancoran Mas, Depok \\ E-mail: Irbihat@ dkp.go.id
}

\begin{abstract}
ABSTRAK
Indonesia diharapkan menjadi Negara Penghasil Produk Kelautan dan Perikanan Terbesar Tahun 2015. Sektor kelautan dan perikanan sebagai salah satu penggerak utama (primemover) perekonomian, perlu terus ditingkatkan produksinya sehingga akan dapat meningkatkan kesejahteraan masyarakat kelautan dan perikanan. Ikan hias yang diperdagangkan di dunia mencapai 1.600 jenis, di mana 750 jenis di antaranya adalah ikan air tawar. Pada tahun 2010, Indonesia menargetkan ekspor ikan hias akan meningkat sebesar 10\% Upaya dalam mendorong pengembangan kawasan perikanan budidaya di daerah-daerah dalam rangka meningkatkan pertumbuhan perekonomian, maka dilakukan program minapolitan. Dukungan penelitian terhadap program minapolitan khususnya budidaya ikan hias antara lain dalam pengembangan ikan hias yang bersifat konvensional (maskoki, guppy, cupang hias); pemanfaatan sumberdaya genetik baru dari alam yang dapat didomestikasi (rainbow), peningkatan produksi ikan hias dengan nilai ekonomi tinggi/ mahal (arwana, botia), dan tren (tigerfish) baik berupa paket teknologi maupun penerapan di masyarakat secara langsung. Dalam tulisan ini dikemukakan prospek dan peluang serta program pengembangan dan dukungan penelitian bagi pengembangan budidaya ikan hias.
\end{abstract}

KATAKUNCl: ikan hias, minapolitan, produksi budidaya ikan hias

\section{PENDAHULUAN}

Sumbangan budidaya ikan hias terhadap penyediaan produk perikanan masih relatif kecil, tetapi terus menunjukkan kecenderungan meningkat dari tahun ke tahun. Hal ini tidak saja terjadi di Indonesia melainkan juga di seluruh dunia. Meskipun sebagian sumberdaya perikanan terutama di laut belum dimanfaatkan, ada gejala bahwa usaha penangkapan semakin sulit karena biaya operasional, perubahan tingkah laku ikan oleh perubahan iklim global dan persaingan yang semakin berat. Sementara budidaya semakin menunjukkan peranannya sebagai tumpuan usaha perikanan di masa depan. Hal tersebut antara lain disebabkan adanya beberapa kelebihan budidaya dibandingkan penangkapan dan kemajuan IPTEK termasuk teknologi pembenihan yang dapat menyediakan bibit unggul sehingga dapat melipatgandakan hasil produksi.

Tahun 2010 merupakan tahun yang sangat bermakna dan sangat berarti dalam sejarah pembangunan kelautan dan perikanan, karena tahun ini merupakan tahun pertama kerja keras kita dalam mewujudkan Indonesia sebagai Negara Penghasil Produk Kelautan dan Perikanan Terbesar Tahun 2015. Sebagaimana Visi Kementerian Kelautan dan Perikanan yang telah kita cita-citakan bersama, menjadikan sektor kelautan dan perikanan sebagai salah satu "prime mover" perekonomian di Indonesia, sehingga kita secara bersama-sama berupaya terus meningkatkan kesejahteraan masyarakat kelautan dan perikanan. Pada akhirnya profesi nelayan, pembudidaya ikan, serta para pengolah hasil perikanan diharapkan menjadi masyarakat yang berpendapatan dan bukan lagi menjadi profesi yang identik dengan kemiskinan (Muhammad, 2010).

Salah satu keanekaragaman hayati yang dimiliki Indonesia dan patut dibanggakan adalah keragaman spesies ikan hias, baik ikan hias air laut maupun air tawar. Ikan hias air laut ada sekitar 650 spesies, sudah teridentifikasi 480 spesies dan diperdagangkan sekitar 200 spesies. Jenis-jenis ikan hias air laut Indonesia yang memiliki nilai jual tinggi di pasaran internasional, antara lain clown fish (Amphiprion ocellaris) dan banggai cardinal fish (Pterapogon kauderni). Pangsa pasar ikan hias air laut Indonesia di dunia internasional sebesar 20\% di mana 95\%merupakan hasil tangkapan dan baru $5 \%$ sisanya merupakan hasil budidaya masyarakat. Sementara itu, jumlah spesies ikan hias air tawar diperkirakan sekitar 400 spesies dari 1.100 spesies ikan hias yang ada di seluruh dunia. Komoditas ikan hias air tawar asal Indonesia yang menjadi favorit 
antara lain, arwana (Schleropages formosus) terutama spesies super red dan red banjar, botia (Chromobotia macracanthus), serta cupang (Beta splendens). Dalam tulisan ini akan disampaikan prospek dan peluang pengembangan ikan hias. Program minapolitan, dukungan riset serta difusi teknologi yang dilakukan.

\section{PROSPEK DAN PELUANG PENGEMBANGAN IKAN HIAS}

Kegiatan usaha ikan hias memiliki beberapa keunggulan komparatif, di antaranya bisa dengan modal yang sedikit, dapat dilakukan oleh industri rumah tangga, pasarnya tidak pernah jenuh, pengembangan strain baru dapat dilakukan secara indvidu, dan kegiatan usaha ini dapat memberdayakan masyarakat melalui industri kecil yang bermuara pada ekspor. Namun demikian, kegiatan usaha ikan hias tidak terlepas dari beberapa masalah, di antaranya penyediaan indukan, bibit unggul, pembenihan, promosi, dan distribusi.

Jumlah ikan hias yang diperdagangkan di dunia mencapai 1.600 jenis, di mana 750 jenis di antaranya adalah ikan air tawar. Dalam perdagangan ikan hias global, Indonesia memiliki pangsa pasar sebesar 9,5\% sedangkan Singapura telah mencapai 22,8\% Dari jumlah tersebut 90\% dari kebutuhan ikan Singapura tersebut disuplai dari Indonesia. Sedangkan negara importir terbesar ikan hias selama ini berturut-turut adalah Amerika Serikat (25,3\%); Jepang (11,6\%); dan Jerman (9,2\%). Potensi Indonesia yang sangat besar ini dapat menjadi potensi ekonomi yang positif bagi kesejahteraan masyarakat (Anonim, 2010).

Pada tahun 2010 ini Indonesia menargetkan ekspor ikan hias akan meningkat sebesar $10 \%$ Indonesia akan melakukan pembenahan dan penanganan lebih baik mengenai pengembangan budidaya ikan tersebut. Indonesia memiliki potensi ikan hias yang sangat besar dengan potensi sekitar 1,5 miliar ekor. Negara tujuan ekspor jenis ikan hias air tawar dan laut Indonesia adalah Singapura, Cina, Hongkong, Malaysia, Jepang, Korea Selatan, Amerika, Timur Tengah, dan Uni Eropa. Nilai penjualan ikan hias Indonesia ke luar negeri setiap tahunnya cenderung mengalami peningkatan, namun masih belum cukup signifikan dibandingkan dengan besarnya potensi sumberdaya ikan hias yang dimiliki Indonesia (Muhammad, 2010).

Berdasarkan kondisi tersebut, para pembudidaya dan pengusaha perlu mendorong pengembangan komoditas ikan hias sebagai penghasil produk kelautan dan perikanan terbesar di dunia pada tahun 2015. Untuk mencapai target tersebut diperlukan langkah-langkah di antaranya memperkuat kelembagaan dan SDM secara terintegrasi, mengelola sumberdaya perikanan dan kelautan secara berkelanjutan, meningkatkan produktivitas dan daya saing berbasis pengetahuan serta memperluas akses pasar domestik dan internasional.

\section{PROGRAM MINAPOLITAN IKAN HIAS}

Minapolitan merupakan konsep pembangunan kelautan dan perikanan berbasis wilayah dengan pendekatan dan sistem manajemen kawasan dengan prinsip-prinsip, integrasi, efisiensi, kualitas, dan akselerasi. Pengembangan Kawasan Minapolitan merupakan upaya dalam mendorong pengembangan kawasan perikanan budidaya di daerah untuk meningkatkan perekonomian dan pertumbuhan wilayah dengan kegiatan perikanan budidaya sebagai penggerak utama. Sektor kelautan dan perikanan masih dianggap kecil dan kurang strategis. Dengan program minapolitan, diharapkan, sektor ini dapat memberikan kontribusi yang cukup signifikan dalam mendorong perekonomian nasional. Pemanfaatan potensi daerah secara optimal, akan meningkatkan perberdayaan masyarakat.

Program minapolitan merupakan program yang secara fungsional bertumpu pada kegiatan sektor perikanan dengan basis pengembangan komoditas unggulan baik pada kegiatan budidaya laut, air payau maupun air tawar. Pengembangan kawasan minapolitan merupakan bentuk penjabaran dan implementasi Undang-Undang No. 26 Tahun 2007 tentang Penataan Ruang, khususnya di dalam upaya pengentasan kemiskinan melalui pengembangan kawasan perdesaan yang bertumpu pada pembangunan agribisnis dalam arti luas serta terkoordinasikan dalam sistem pembangunan wilayah secara terpadu dan berkesinambungan (Bakrie, 2010).

Tujuan pengembangan kawasan minapolitan adalah untuk mendorong percepatan pengembangan wilayah dengan kegiatan pertanian, terutama perikanan sebagai kegiatan utama untuk meningkatkan kesejahteraan masyarakat. Adapun persyaratan suatu kawasan dapat dijadikan kawasan minapolitan adalah sebagai berikut (Anonim 2009):

1. Memiliki sumberdaya lahan/perairan yang sesuai untuk pengembangan komoditas perikanan

2. Memiliki berbagai sarana dan prasarana minabisnis yang memadai

3. Memiliki sarana dan prasarana umum yang memadai seperti transportasi, jaringan listrik, telekomunikasi, air bersih, dan lain-lain.

4. Memiliki sarana dan dan prasarana kesejahteraan sosial/ masyarakat yang memadai seperti kesehatan, 
pendidikan, kesenian, rekreasi, perpustakaan, swalayan, dan lain-lain.

5. Kelestarian lingkungan hidup, baik kelestarian sumberdaya alam, kelestarian sosial budaya maupun keharmonisan hubungan kota dan desa terjamin.

Dalam lima tahun ke depan, Kementerian Kelautan dan Perikanan (KKP) akan membangun kawasan minapolitan di 28 kabupaten sebagai pilot project untuk meningkatkan produksi perikanan di Indonesia baik ikan hias maupun konsumsi. Daerah yang dapat berpotensi sebagai kawasan pengembangan budidaya ikan hias dalam program minapolitan tersebut antara lain Blitar, Tulung Agung, Banyuwangi, dan Sleman.

Potensi Kabupaten Blitar, Jawa Timur, sebagai kawasan minapolitan ikan hias merupakan sentra ikan hias koi. Secara nasional daerah ini memasok $80 \%$ produk ikan hias. Pada 2005, dibangun sub riser ikan hias di kawasan Penataran. Dinas Perikanan dan Kelautan Blitar tengah merencanakan proyek minapolitan khusus ikan hias koi. Lokasi program ditetapkan Desa Penataran, Kemloko, Krenceng, dan Bangsri yang selama ini menjadi sentra budidaya ikan koi di samping 14 kecamatan lainnya. Produksi ikan-ikan koi di Daerah Blitar disajikan pada Gambar 1.

Kabupaten Tulung Agung juga merupakan daerah yang berpotensi sebagai kawasan pengembangan produksi ikan maskoki. Daerah ini juga diusulkan sebagai kawasan program minapolitan. Sampai saat ini, Kabupaten Tulung Agung masih merupakan pemasok ikan maskoki terbesar di Indonesia, walaupun kawasan budidaya di daerah ini tidak seluas ikan koi di Daerah Blitar.

Komoditas ekspor Kabupaten Banyuwangi masih mengandalkan hasil perikanan dan kelautan. Komoditas

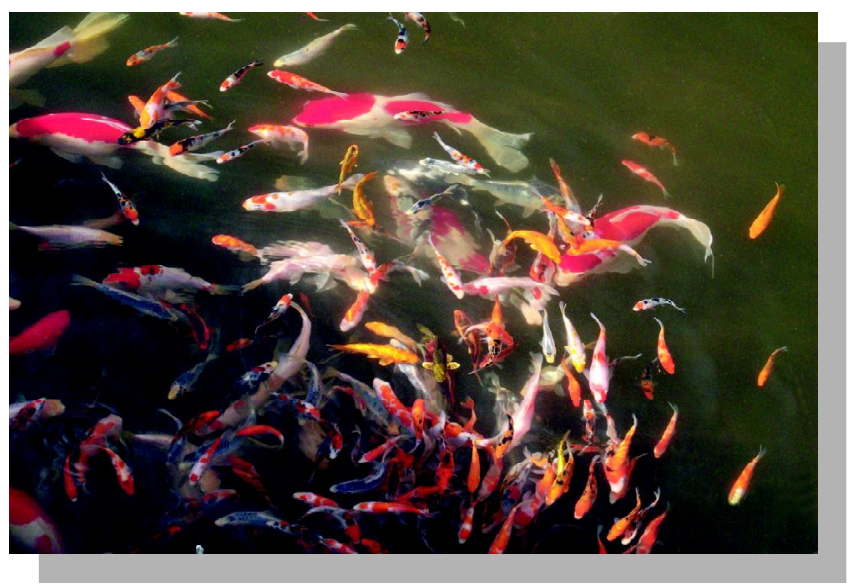

Gambar 1. Ikan-ikan koi hasil budidaya petani di Daerah Nglegok, Blitar eskpor terbesar selama ini disumbang oleh usaha ikan hias, udang serta ikan kaleng atau sarden. Tahun Ialu ekspor ikan hias menempati urutan pertama senilai Rp 2,8 miliar. Tujuan ekspor produk itu antara lain Jepang, Taiwan, Hong Kong, Cina, dan Jerman. Ada lima perusahaan di bidang ekspor ikan hias laut. Produknya antara lain jenis Angle piyama, Angle napoleon, dan Angle doreng (Gambar 2).

Program minapolitan ikan hias di Provinsi Daerah Istimewa Jogjakarta adalah Kabupaten Sleman, tepatnya Kecamatan Berbah. Kelebihan Berbah sebagai rencana kawasan minapolitan di samping beragamnya varietas ikan yang ada, terutama ikan hias yang memiliki nilai ekonomis tinggi, juga dari semangat masyarakat di Berbah yang sangat antusias terhadap kegiatan budidaya perikanan ini. Beberapa kelompok tani ikan di Berbah telah menjuarai kompetisi, baik ditingkat regional maupun nasional di bidang kegiatan budidaya perikanan. Potensi pelaku kegiatan di bidang perikanan di Kecamatan Berbah mencapai $60 \%$ dari seluruh penduduk. Persyaratan yang harus dipenuhi selain $80 \%$ pelaku minapolitan di kabupaten tersebut, adalah perlunya industri pengolahan ikan yang harus ditingkatkan persentasenya.

Jumlah petani ikan di Kecamatan Berbah pada tahun 2009 mencapai 743. Sedangkan luas total kolam ikan di Kecamatan Berbah untuk pembesaran pada tahun 2009 mencapai $325.150 \mathrm{~m}^{2}$. Total produksi ikan di Kecamatan Berbah pada tahun 2009 mencapai $442.290 \mathrm{~kg}$. Sistem irigasi untuk pertanian, khususnya perikanan sudah cukup baik dengan mengambil air dari Sungai Kuning, Tepus, dan Opak melalui 17 buah bendung. Budidaya perikanan yang dilakukan di Kecamatan Berbah meliputi pembenihan dan pembesaran. Komoditas unggulan ikan Arwana cocok dikembangkan di Berbah. Komoditas perikanan lainnya

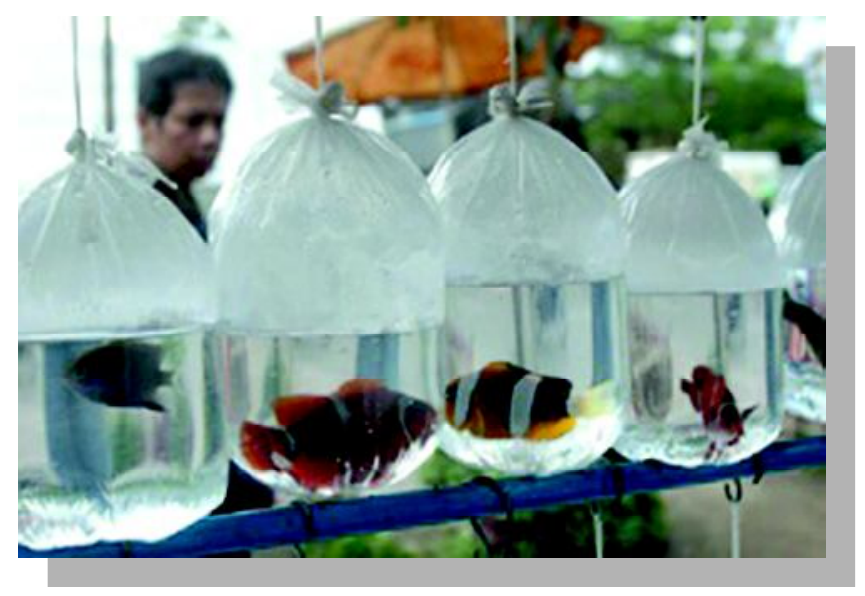

Gambar 2. Jenis-jenis ikan hias laut yang diekspor dari Banyuwangi 
yang dikembangkan antara lain meliputi ikan cupang. Komoditas ikan Arwana dan ikan cupang memiliki nilai ekonomis yang lebih tinggi dibandingkan hasil pertanian berupa padi.

\section{DUKUNGAN PENELITIAN IKAN HIAS}

Pengembangan IPTEK terhadap ikan hias secara khusus di Indonesia baru mulai dilakukan sejak tahun 2005, tahap inventarisasi, koleksi, domestikasi, reproduksi, pembenihan, pengelolaan pakan, pengelolaan lingkungan, dan penanggulangan penyakit. Penelitian ikan hias air tawar yang telah dirintis dan berhasil dilakukan di Balai Riset Budidaya Ikan Hias mencakup beberapa komoditas baik yang bersifat konvensional, komoditas baru, komoditas eksotis yang bernilai ekonomi tinggi, maupun tren. Sebagai riset ikan hias yang mampu mendukung keberhasilan pembangunan perikanan secara keseluruhan di antaranya yang berupa inovasi teknologi yang dapat diaplikasikan di masyarakat. Perlu diakui bahwa riset yang dilakukan dan teknologi budidaya ikan hias air tawar di Indonesia selangkah lebih maju dibandingkan dengan ikan hias laut. Menurut Lusiastuti et al. (2008), saat ini telah bertambah sekitar 10 jenis ikan hias air tawar yang dapat dibudidayakan, selain jenis-jenis yang sudah lama berkembang di masyarakat yaitu neon tetra, rednose, blue eyes, mancase, black panthom, red panthom, rosy, silver dollar, guppy, dan black gost. Untuk penelitian ikan hias laut sampai saat ini masih kurang mendapat perhatian dari berbagai kalangan.

Teknologi budidaya skala laboratorium dan teknologi produksi skala besar yang dihasilkan serta telah dikuasai dan dapat diterapkan untuk ikan hias air tawar di antaranya ikan botia dan balashark. Ikan botia (Chromobotia macracanthus Bleeker) atau clown loach merupakan spesies ikan hias air tawar dari Famili Co bitidae yang distribusinya terbatas di Pulau Sumatera dan Kalimantan. Pembenihan ikan hias botia di luar habitat aslinya (ex situ) sudah berhasil dilakukan namun masih dalam skala laboratorium (Satyani et al., 2006) (Gambar 3). Benih merupakan salah satu produk yang sangat menentukan keberhasilan usaha budidaya ikan hias botia. Kualitas warna juga harus mendapat perhatian khusus karena warna merupakan standar mutu ikan hias botia di dalam perdagangannya.

Proses domestikasi adalah hal pertama yang harus mendapat perhatian serius karena kondisi habitat ikan hias botia berbeda dengan habitat barunya di tempat pembenihan (budidaya). Pada tahun 2004 mulai mengoleksi ikan botia dari Sungai Musi. Hasil analisis GSI menunjukkan baik induk betina dan jantan meningkat mulai bulan September hingga Desember (Legendre, 2007). Pada tahun 2006 beberapa calon induk botia dikoleksi dari perairan Sumatera dan Kalimantan dan dipelihara secara terpisah dalam bak kanvas dalam ruangan yang dapat diatur suhunya. Penelitian yang terkait dengan pakan meliputi pakan larva dan benih. Pakan awal larva yaitu infusoria, rotifer nauplii Artemia sampai umur 21 hari (Satyani et al., 2007). Riset pakan yang terkait dengan benih menunjukkan bahwa hingga umur tiga bulan, cacing darah (tubifex) paling baik memberikan respons terhadap sintasan dan pertumbuhan benih (Chumaidi \& Priyadi, 2006).

Ikan balashark (Balantiocheilus melanopterus) telah berhasil dipijahkan di luar habitatnya (ex situ) oleh peternak ikan dengan cara kawin suntik. Informasi yang berkembang di tingkat pembudidaya adalah ikan yang berhasil dibudidayakan oleh petani pembenih adalah jenis yang berasal dari Thailand (Sudarto \& Yulianti, 2007) (Gambar 4). Menurut Zairin et al. (1996), reproduksi ikan balashark memijah satu kali dalam satu tahun dan terjadi pada musim penghujan. Pada awalnya penelitian

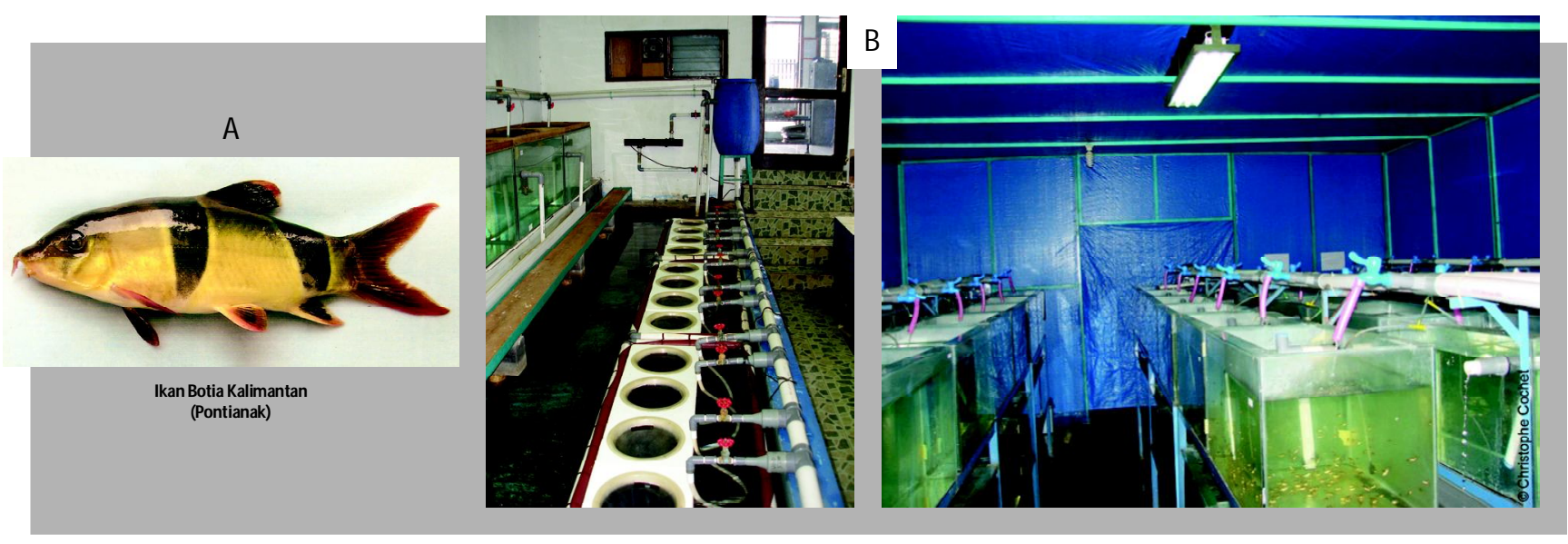

Gambar 3. Induk botia matang gonad (A), peralatan pembenihan ikan botia (B) 


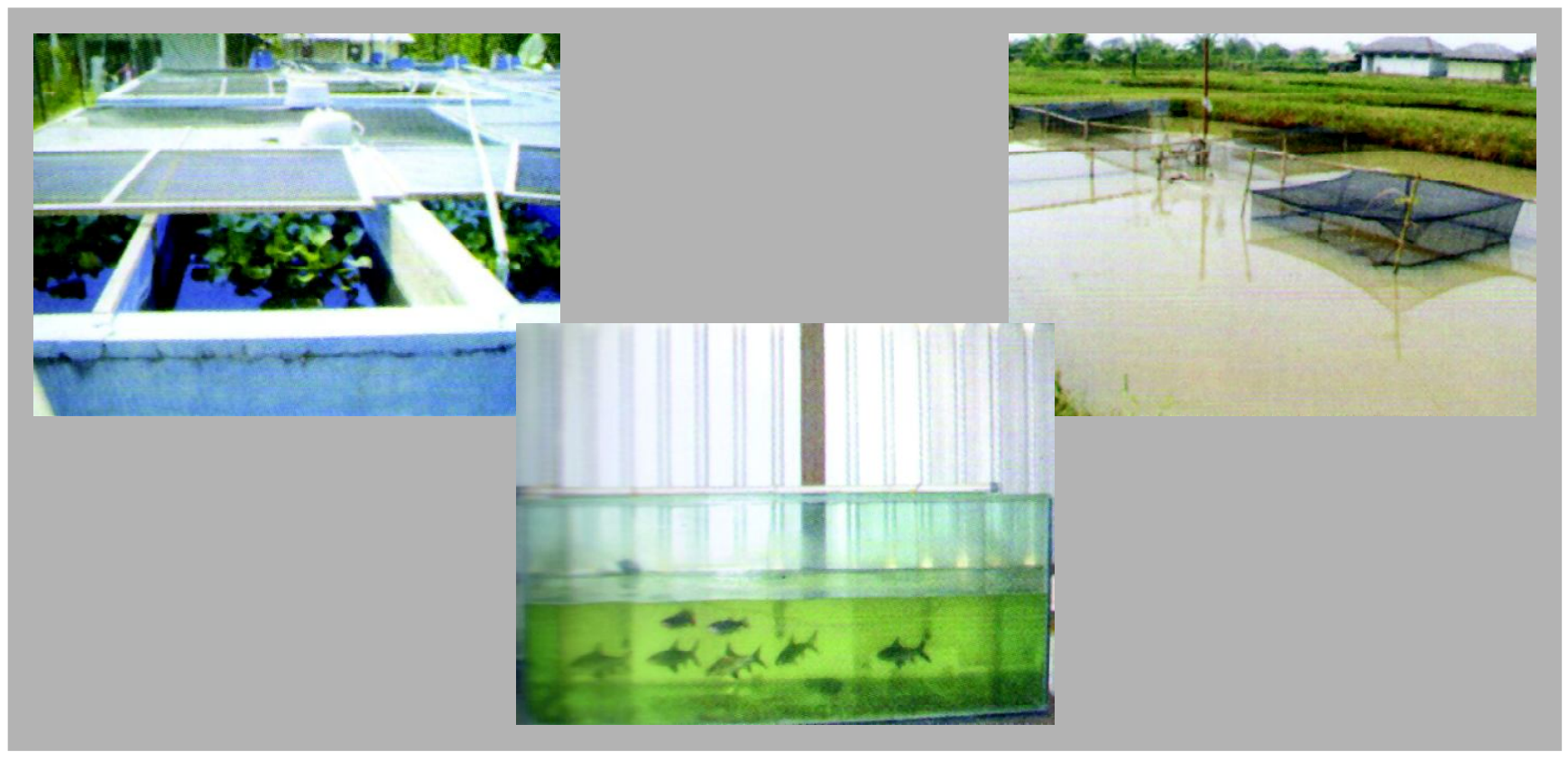

Gambar 4. Pembenihan ikan balashark di bak beton, hapa, dan akuarium

pematangan gonad dalam berbagai wadah menunjukkan bahwa gonad kurang berkembang dalam pemeliharaan di akuarium. Sedangkan pemeliharaan dalam bak beton dan kolam tanah menunjukkan perkembangan gonad yang baik serta dapat dipijahkan. Pemijahan hanya dapat dilakukan dengan pemijahan buatan menggunakan ovaprim dan HCG.

Selain ikan hias air tawar, potensi sumberdaya kelautan adalah ikan hias laut, yang belum mendapatkan perhatian yang maksimal. Padahal ada beberapa jenis mempunyai nilai jual yang tinggi di pasaran internasional di antaranya clown fish (Amphiprion ocellaris) dan banggai cardinal fish (Pterapogon kauderni). Pemeliharaan teknologi budidaya ikan-ikan hias laut walaupun sudah dimulai namun secara maksimal di Indonesia belum dikuasai sehingga perlu diadakan penelitian lebih lanjut guna menghasilkan indukinduk unggul yang dapat diadopsi oleh para "stakeholder".
Penelitian ikan clown fish ini sudah dapat memproduksi benih. Induk-induk yang didatangkan dari Laut Madura dan Sulawesi telah dikoleksi oleh Balai Besar Riset Perikanan Budidaya Laut untuk didomestikasikan dan sudah dapat memijah menghasilkan benih dalam akuarium yang berukuran $60 \mathrm{~cm} \times 40 \mathrm{~cm} \times 30 \mathrm{~cm}$ dengan sistem air mengalir seperti dapat dilihat pada Gambar 5. Pakan yang diberikan sejak domestikasi adalah pakan buatan, nereis dan jembret.

\section{PENERAPAN TEKNOLOGI}

Berdasarkan data statistik ikan hias dunia, bahwa ikan hias tawar dan laut yang beredar di pasar internasional saat ini 95\% merupakan hasil tangkapan alam dan 5\% merupakan hasil budidaya masyarakat (Poernomo, 2008). Tanpa disadari bahwa eksploitasi yang dilakukan selama ini telah mengalami over fishing. Oleh karena itu, kegiatan

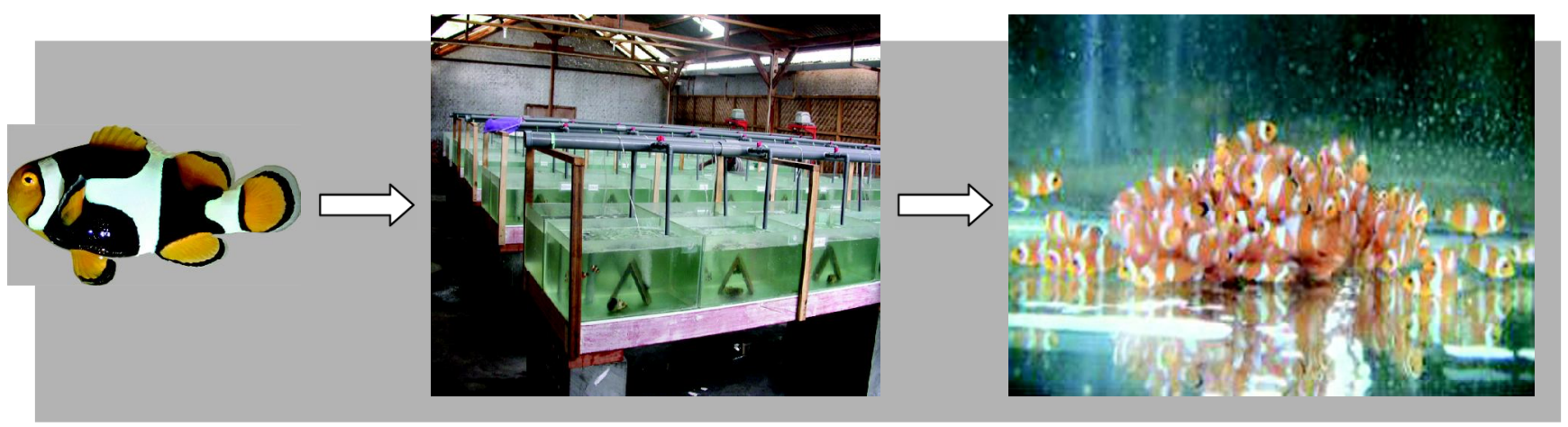

Gambar 5. Pembenihan ikan clown fish (Amphiprion ocellaris) 
budidaya jenis-jenis ikan hias tawar dan laut sangat penting untuk dikembangkan selain untuk memenuhi permintaan pasar yang semakin meningkat juga untuk menjaga kelestarian plasma nutfah. Tujuan lain yang tidak kalah penting adalah meningkatkan penghasilan bagi petani dan nelayan ikan hias, yang akhirnya meningkatkan kesejahteraan masyarakat. Pengembangan budidaya ikan hias akan berdampak positif dalam berbagai aspek di antaranya mendayagunakan potensi yang ada sehingga dapat mendorong kegiatan produksi berbasis ekonomi rakyat, meningkatkan perolehan devisa, dan mempercepat pembangunan ekonomi masyarakat perikanan secara keseluruhan. Guna pencapaian tujuan tersebut, perlu pemantapan teknologi yang telah dikuasai agar segera dapat disosialisasikan dan diaplikasikan kepada masyarakat.

Pemerintah pada beberapa tahun ini menggalakkan penerapan teknologi perikanan untuk masyarakat yang disebut IPTEKMAS. IPTEKMAS (IImu Pengetahuan dan Teknologi untuk Masyarakat) adalah penerapan ilmu pengetahuan dan teknologi untuk masyarakat di bidang kelautan dan perikanan. Kegiatan IPTEKM AS bertujuan untuk mengembangkan dan meningkatkan sumberdaya yang ada menjadi lebih baik di kemudian hari. IPTEKM AS di bidang kelautan dan perikanan sangat penting dalam menyukseskan program pemerintah yang mengedepankan ilmu pengetahuan dan teknologi dan sangat diharapkan dalam meningkatkan kesejahteraan dan kehidupan masyarakat kelautan dan perikanan.

\section{DAFTAR ACUAN}

Anonim. 2009. Pengembangan Kawasan Minapolitan. Pedoman Umum. Direktorat Prasarana dan Sarana, Direktorat Jenderal Perikanan Budidaya, $33 \mathrm{hlm}$.

Bakrie, Z. 2010. Minapolitan untuk Pembangunan Sektor Perikanan. Dinas Kelautan dan Perikanan Kabupaten Luwu Timur, $3 \mathrm{hlm}$.

Chumaidi \& Priyadi, A. 2006. Pendederan benih botia (Chromobotia macracanthus) dengan pemberian berbagai pakan hidup. Prosiding Semaskan UGM . Hasil Penelitian Perikanan dan Kelautan, hlm. 282-287.

Legendre, M. 2007. Investigation on Artificial Propagation of Local Species. Project FISH-DIPA 2006-2007, hlm. 172194.

Lusiastuti, A.M., Aryati, Y., Supriyadi, H., \& Praseno, 0. 2008. Analisis Kebijakan Pengembangan Budidaya Ikan Hias dan Ikan Konsumsi di Kabupaten Bogor. Buku Analisis Kebijakan, Pusat Riset Perikanan Budidaya, hlm. 71-80.

Muhammad, F. 2010. Pembangunan Perikanan. Sambutan Menteri Kelautan dan Perikanan HUT RI 2010, $4 \mathrm{hlm}$.

Muhammad, F. 2010. Target Ekspor Ikan Hias di Indonesia 2010. Bussines News Jakarta, 11 Mei 2010, $1 \mathrm{hlm}$.

Poernomo, S.H. 2008. DKP dan LIPI Kembangkan Ikan Hias. Data Statistik dan Informasi 2008. http:// www.indonesia.go.id diakses 1 Oktober 2010, $3 \mathrm{hlm}$.

Poernomo, S.H. 2010. Tingkatkan Pembangunan Kelautan dan Perikanan. Data Statistik dan Informasi 2010, Kementrian Kelautan dan Perikanan, $2 \mathrm{hlm}$.

Satyani, D., Mundriyanyo, H., Subandiyah, S., Chumaidi, Taufik, P., Slembrouck, J., Legendre, M., \& Pouyaud, L. 2006. Teknologi Pembenihan Ikan Hias Botia (Chromobotia macracanthus) Skala Laboratorium Loka Riset Budidaya Ikan Hias Air Tawar Depok, $26 \mathrm{hlm}$.

Sudarto \& Yuliati, P. 2007. Pengenalan ikan balashark Balantiocheilus melanopterus dalam Chumaidi, Satyani, D., \& Sudarto. 2007. Teknik Pembenihan Ikan Balashark, Balantiocheilus melanopterus. Loka Riset Budidaya Ikan Hias Air Tawar, hlm. 5-11.

Zairin, M.Jr., Sumantadinata, K., \& Arfah, H. 1996. Aplikasi Bioteknologi pada Reproduksi Ikan Balashark (Balantiocheilus melanopterus Bleeker) dalam Upaya Mempertahankan Keragaman Spesies dan Sumber Daya Perikanan, Depatemen Budidaya Perikanan, Institut Pertanian Bogor, $104 \mathrm{hlm}$. 